application, and no injury to any of the plants was observed. Although no special apparatus is essential, the following method for distribution is suggested. A water suction pump (ejector) is attached to the garden tap, and hose piping leads from the suction opening into the barrel containing ammonium sulphide solution. The distributing hose is connected to the other end of the filter pump. On turning on the tap, the solution is drawn off from the barrel, mixed with water from the tap, and forced through the distributing hose. Calculation and trial are of course needed to determine the strength of ammonium sulphide solution in the barrel in order to yield 1 part in 30 in the distributing hose. Mr. Van Riper would welcome the reports of other experience in the use of this method for slug eradication.

\section{Narcissus Pests}

Bulletrin No. 51 of the Ministry of Agriculture and Fisheries (May 1932), entitled "Narcissus Pests", by Mr. W. E. H. Hodson, has recently come to hand. The object of this publication is to provide growers with reliable and up-to-date information enabling them to control the more common and destructive of the enemies of the narcissus. The Bulletin deals with the species of flies of which the larvæ are persistent enemies of the bulbs, while eelworms, mites, and other pests are also fully discussed. The most satisfactory treatment for all such pests is the submersion of the bulbs in water maintained at a temperature of $110^{\circ} \mathrm{F}$. for three hours. If such treatment were not available it is highly probable that the bulb eelworm would by now have rendered commercial growing almost impracticable. The Bulletin is obtainable, price 18. net, from H.M. Stationery Office or through any bookseller.

\section{Penguins' Eggs}

THE appearance of the eggs of penguins in some of the large London stores, where they were sold as epicurean novelties at ten shillings a dozen, led the Royal Society for the Protection of Birds to make inquiries regarding the source and supply (Bird Notes and News, vol. 15, No. 2, p. 39, 1932). The eggs were those of the Cape or black-footed penguin (Spheniscus demersus), and were obtained in one of the extensive penguin rookeries in the Cape Province of the Union of South Africa. The eggs were collected for sale under Government regulation, and the Trade Commissioner for South Africa informed the Society that during the months of April and May of the present year some 2000 dozen of the eggs were exported to Great Britain. We hope that the Government department which regulates the taking of the eggs will see to it that the strength of the penguin colony is not too seriously reduced, remembering the fate of the gare-fowl when commerce invaded its innumerable hordes ; and we trust that the exceptional opportunity will be taken of associating the statistics of eggs taken with the total strength of the colony year by year, for the study of the effect upon the population of the colony as a whole.

\section{Monument to Laplace}

THE issue of Revue Scientifique for Aug. 13 briefly records the inauguration on July 3 of a monument to the great French mathematician, Laplace, at his birthplace, Beaumont-en-Auge (Calvados). The monument, which is the work of M. R. Delandre, has been erected by international subscription, among the principal contributors to which were Messrs. J. H. Fry and J. Flanagan, of the United States, and the two Carnegie Foundations for Science and Peace. The unveiling took place in the presence of Maréchal Franchet d'Esperey, of the Société de Géographie of Paris, and distinguished representatives of the Academy of Sciences, the Paris Observatory, and the École Polytechnique. As recorded in NATURE for April 2, 1927, p. 493, at his death in March 1827 Laplace was buried in the Père Lachaise cemetery in Paris, but sixty-one years later, in 1888 , his remains were exhumed and reinterred in the grounds of the family estate at the little hamlet of Saint Julien de Mailloc, situated between Lisieux and Orbec (Calvados). At the time of the reinterment, the monument which had marked the resting-place of Laplace in Paris was presented to the commune of Beaumonten-Auge, and was re-erected in the cemetery there.

\section{Discovery of the Deviation of the Compass}

In the July issue of Science Progress, Mr. N. H. de V. Heathcote brings together the data at present available for fixing the date of the discovery of the deviation of the compass from true north. The figure in the instructions of the Nautical Chart of Bianco of 1436 which has been taken as evidence that a correction for a deviation of $18^{\circ}$ west of true north was allowed for, the author concludes has nothing to do with deviation. The first definite record of deviation he considers to be that made by Columbus in September 1492, during his first voyage across the Atlantic. In his record of his return in 1496 from his voyage to India, Columbus mentions Flemish compasses which read $111^{\circ}$ west of north when the Genoese compasses read north. Mr. Heathcote points out that pocket sundials were in use in Germany about the middle of the fifteenth century which were set in the meridian by a compass; in the latter an allowance for a deviation of $6^{\circ}$ east of true north was made, while in Etzlaub's road map of Germany of 1492 instructions are given for orienting it correctly by compass, an allowance for deviation of $111^{\circ}$ being made. He concludes that pocket sundials with an arrow set $114^{\circ}$ east of north were familiar objects in Germany before the time of Columbus.

\section{Bibliography of Line Spectra}

No better comment could be made on the present importance of line spectroscopy than the publication by the American Physical Society in Reviews of Modern Physics (April) of a bibliography of the papers which have appeared between 1920 and 1931. This has been compiled by R. C. Gibbs, and is prefaced by a short elementary account of the interpretation of spectra. The bibliography is divided into three sections. The first, which contains the majority of the references, is a list of those papers which contained new data or discussions; these are divided according to elements, stage of ionisation, year of publication, and alphabetical order of authors, and in general, when one paper has dealt with several elements, it

No. 3279, VoL. 130] 
has been listed under each to avoid cross-references. The two other sections are much shorter, and deal with more general publications, articles mainly concerned with the mathematical machinery of quantum mechanics not being included. The lists occupy some 150 pages of small print, and although essentially uncritical, should be of the utmost value to all workers in spectroscopy.

\section{Progress in Modern Physics}

IN his introduction to a set of pamphlets on recent developments in physics ("Exposés de physique théorétique ") published by Hermann et Cie, of Paris ( 6 francs each), Prof. L. de Broglie raises once more the question of how contact can be maintained between workers at different branches of physics. It is now quite impossible for any one person both to read critically all new papers, in any but a most limited field, and to advance the subject himself. Realisation of this is, of course, not new, and has inspired, amongst other publications, the American Physical Society's Reviews of Modern Physics. The present series seems likely, however, to fulfil its purpose better than anything that has gone before. Although definitely for advanced workers, the articles are anything but abstracts, being well written and critical, and containing adequate detail without providing what is really irrelevant to anyone not a specialist in the particular subject dealt with. They also deal with relatively new or very recent work. Of the two at present under notice, Prof. de Broglie's is based on Landau and Peierl's treatment of the uncertainty principle (Z. Phys., vol. 69, p. 56), and is purely theoretical. The other, by Irène Curie and F. Joliot, is an account of the neutron experiments, particularly those done by the workers in Paris; it contains an interesting set of reproductions of Wilson cloud trails, which supplement those recently published by Feather and Dee in the Proceedings of the Royal Society. Each article occupies a little more than twenty pages, and although attractively presented, is certainly cheap.

\section{Cadastral Survey and Land Records}

DURING the Conference of Empire Surveyors held in London last year, there was exhibited at the Science Museum a number of cadastral survey, land registry, and land revenue records. The Royal Geographical Society, at the instance of the Secretary of State for the Colonies, has arranged to house these exhibits, and hopes to make them the nucleus of a permanent reference collection in London. It is expected that the collection will include land laws, regulations, and technical instructions from all parts of the world, and will be representative of progressive advances in cadastral survey and land records in each country. Sir Ernest Dowson and Mr. V. L. O. Sheppard have jointly undertaken the collection, study, and maintenance of the documents.

\section{Oil Fuel for Horticultural Purposes}

THE seventeenth annual report (1931) of the Cheshunt Experimental and Research Station contains a short account of a test with an automatic heating installation using oil fuel. A thermostat in the tomato greenhouse controls the action of a crude oil burner which gives heat to a special hot-water heating boiler. The account is quite short and the experiment incomplete, but the results show that an enhanced yield can be expected from the increased night temperature. Moreover, the fungus disease known as tomato leaf mould was kept in check by the higher temperature.

\section{Announcements}

THE thirty-sixth autumn fungus foray and annual general meeting of the British Mycological Society will be held at Haslemere, Surrey, on Sept. 19-24. Miss G. Lister will deliver the presidential address, entitled "Field Notes on Mycetozoa", on Sept. 21. Several interesting local excursions have been arranged in connexion with the meeting

THe Society of Biological Chemists (India) has made itself responsible for an interesting pamphlet, "Biochemical and Allied Research in India in 1931 ", in which in about forty pages Indian biochemical research in different fields is summarised in a series of brief reviews by some six contributors. The papers cited, of which the majority appear to have been published in 1930 and 1931, number no less than 181. These brief summaries are grouped under various sub-headings-for example, enzymes and fermentation, agricultural chemistry, chemistry of nutrition, etc.-and seem to be very concisely done, so that this little pamphlet should be useful to many biochemical workers outside India.

The Society of Petroleum Geophysicists (America) has issued volume 1 of its Transactions, comprising a series of important papers presented by the Society at the annual convention of the American Association of Petroleum Geologists at San Antonio in March 1931. Most, if not all, of these papers have appeared in the Bulletin of the Association, but now they are available in a convenient, compact form. The titles are: "Application of Seismography to Geological Problems", by E. McDermott; "Belle Isle Torsion-Balance Survey", by D. C. Barton; "Some Results of Magnetometer Surveys in California", by E. D. Lynton; "Magnetic Disturbance caused by Buried Casing", by W. M. Barret ; "Brunton Compass Attachment for Measurement of Horizontal Magnetic Intensity", by J. H. Wilson; "Utilization of Existing Wells in Seismographic Work", by B. McCollum and W. W. La Rue; and an "Analysis of some Torsion-Balance Results in California", by R. H. Miller. The editor is F. H. Lahee, and an introduction has been written by G. H. Westby. The volume can be obtained in England from Messrs. Thomas Murby and Co.

Applications are invited for the following appointments, on or before the dates mentioned :-A male junior assistant (chemistry) at the Experimental Station, Porton, near Salisbury (War Department)-The Chief Superintendent, Chemical Defence Research Department, 14 Grosvenor Gardens, S.W.1 (Sept. 12). A chief workshop instructor in the Mechanical Engineering Department at the Northampton Polytechnic Institute, St. John Street, E.C.1-The Principal (Sept. 15). 